\title{
Intercultural Dialectic in Communication among Local Transmigrant Employees in Manggarai-Indonesia
}

\section{Fatmawati, Yosefina Rosdiana Su, Tobias Gunas, Yosefina Helenora Jem, and Ely Heldydiana Selamat}

Universitas Katolik Indonesia Santu Paulus Ruteng

\section{Abstract}

This research mainly focused on describing the intercultural dialectic in the interaction among local transmigrant employees in manggarai-NTT. The employees have multicultural background since they come from different regions in indonesia. A descriptive qualitative research design was used to understand the pattern of interaction among mother tongue of each employees, indonesian language, and other local languages that emerge the variation of language in their daily communication. In order to shed light on this issue, the factors that influence the use of the language

Corresponding Author:

Fatmawati

watti_f@yahoo.co.id

Received: 17 February 2020

Accepted: 20 February 2020

Published: 27 February 2020

Publishing services provided by Knowledge E

(c) Fatmawati et al. This article is distributed under the terms of the Creative Commons

Attribution License, which permits unrestricted use and redistribution provided that the original author and source are credited.

Selection and Peer-review under the responsibility of the Isolec Conference Committee. variations were also significant to be considered. The research findings indicated that dialect maintenance, dialect adaptation, the occurrence of other languages, and the emergence of a unique dialect evolved. These patterns occurred due to some factors such as speech situation and topic, keeping the intimacy among the employers, language pride and as a marketing strategy.

Keywords: intercultural dialectic, language variation, local transmigrant employee.

\section{Introduction}

In the recent years, the capital of Manggarai Regency, Ruteng, has been increasingly crowded with the arrival of traders and businessmen from various regions in Indonesia such as Java, Sumatra and Sunda. The presence of the traders from outside the region is certainly influential on the development of language because of course, in communication, there is language interaction among Manggaraian language which is considered as the local language in the context of this research, Indonesian language, and the mother tongue of the new arrivals. This led to the emergence of new language variations. When there is intense interaction between people who come from different cultureal backgroud, there are variations in the language they use. The language used by $A$ can affect the language used by $B$ or vice versa. 
Variations in language that exist in society are systemic and not random Fasold (1984). This variation occurs as a result of the existence of social diversity and the variety of language functions. Although the speaker is in the same speech community, but is not a homogeneous collection of humans, the form of concrete language called parole is not uniform. Diversity or variation in language does not only occur because the speakers are not homogeneous, but also the activities and social interactions they do.

Based on this definition language variation is the use of language according to its usage which varies according to the topic to be discussed. Mansoer Pateda (1987) suggests that variations in language can be seen from the following aspects, (a) based on place; this variation is called a dialect, (b) by time, (c) by user; The person or speaker of the language concerned; (d) based on speakers; (e) based on usage.

This research seeks to answer the following research questions:

1. What are the patterns of interaction among mother tongue, Indonesian language, and local language in daily communication used by the local transmigrant employees?

2. What factors influence the use of language variations by multicultural transmigrant employees?

\section{Method}

This study used descriptive qualitative to describe the intercultural dialectic among local transmigrant employees in restaurants in Manggarai. In order to obtain data, the researchers recorded the interaction among the employees that work in 7 restaurants or food stalls that have employees with intercultural background. The number of employees in each restaurant/ food stalls ranging from 5-11 employees. The recorded interactions were then transcribed to ease the identification of the language variations patterns occurred in the interaction among the employees. Then, the interview was conducted after identifying the interactional patterns in order to figure out the factors that influence the language variation patterns used by the employees.

\section{Findings and Discussion}

In human life, language plays an important role as communication tool. With language human can convey ideas and feelings to others so that relations between humans can be intertwined. In addition, language is also a social identification tool. Through the 
language used by someone we can identify the origin of the person even though they have made adjustments to the local language but their linguistic identities such as accent and intonation cannot be completely eliminated. When speakers of a language interact with speakers of other languages, various language variations will appear. Based on the research findings, there are four patterns of language variation that appear in the interaction among the employees who have a multicultural background. The pattern of language variation will be discussed in the context of the communication of the employees and the factors that influence it.

\subsection{Dialect Maintenance}

Language maintenance and language shift are two terms that appear in multilingual communities. Language maintenance occurs when speakers of a language move to another area that has a different speech language but this group still uses their mother tongue in communication, both between fellow groups and when communicating with other speakers. As explained in the results section that language maintenance in the context of this study is influenced by situation factors, where employees from outside Manggarai, such as Java, Ende, and Maumere use their respective regional dialects when they are seriously working. This is different from a relaxed situation where the dialects used affect one another. The following is a dialogue between one employee from Manggarai (D) and Java (E).

D: "Mas, sebentar ada pesanan yang mau diantar... di Jalan Satar Tacik ntar e".

E: "lya Mbak, tak antarin kalo udah siap”.

Both speakers above have different dialects because each one maintains his dialect in communication. This shows that each person involved in communication provides an opportunity for interlocutors to show their identity (self identity) through language because basically language shows self identity in the form of personal identity, social identity, regional identity or ethnic identity. In the context of the above conversation, language shows ethnic identity, in this case the Manggaraian ethnic group and the Javanese ethnic group. As an ethnic identity, language can be used to indicate ethnicity or membership of a person or group in a particular ethnic group (Santoso, 2006: 46). In connection with the use of language in communication between speakers with different ethnic backgrounds Kloss (1966) as quoted in Pauwels (2012) says that "the attitude of the dominant or majority group toward the language and / or group: although a positive and supportive attitude, the majority of the groups is more likely to be Language Maintenance, in the context of suppression and even persecution". 


\subsection{Language adaptation}

The second pattern of employees' language variations is the adaptation of dialects carried out by those who are from outside Manggarai with the Manggaraian dialect. In addition there is also a mixing code. This can be seen in the conversation excerpt below.

A: "bagaimana mau tidak stroke. dia punya banyak istri e".

$A$ is an employee from Ende and has worked in Manggarai for two years. In the excerpt above, A speaks in Indonesian but the dialect used is the Manggarai dialect which has the characteristic of using the suffixes $-e$ and $-k a$. This can occur because of the language contact that occurs continuously between A and Manggaraian language speakers who are employees with the dominant number at work place. In addition, a number of words included in the category of code mixing in communication used by the employees from outside Manggarai are pronouns, exclamations, and other words that are often used in daily communication. This can be seen in the following excerpt.

C: "eeeh mau beli ayam Chicken satu".

A: "hah!!! ayam chicken? moriiiii".

When a person moves to another place that has a different language, the newcomer will adapt the language to the local community. This causes language shift, in the context above from Ende language or dialect to Manggaraian dialect or language. In connection with the above phenomenon, Chaer (1995: 190) argues that "language shift usually occurs in regions that give hope for better socio-economic life....."

Thus language shifts occur in multilingual communities where speakers from outside try to learn indigenous languages because of the demands of the situation at hand. Keraf (1997: 3) says that "basically, language has certain functions that are used based on a person's needs, namely as a tool to express themselves, as a tool for communication, as a tool to hold integration and adapt socially in a particular environment or situation, and as a tool for social control".

Another factor that influences a person to adapt a language or dialect to native speakers is the factor of speech situation, topic and function of interaction. In the excerpts above, speakers do language adaptation when they are not in a serious work situation (at rest). Besides that, the topic of conversation is also not something that is seriously related to the work they are working on, but rather to things that are jokes, relaxed, personal or other general topics. This is done to build closer relations among the employees, considering their number that only consists of eight workers, based on 
their daily interaction, the researchers could conclude that the relations between them are very close.

In addition to the situation, the interaction function can also be a factor in language adaptation. This can be seen in the language adaptation in official situations also carried out by cashiers from Maumere. On several occasions she used Manggaraian dialect in serving customers. This can be seen in the following excerpt:

F: "Selamat Pagi... Ada yang bisa kami bantu? "

X: "pagi juga. kakak mau pesan pizza satu sama juice alpukat dua e"

F: "pizzanya pakai sosis, jagung atau saus Bolognese? “

X: "yang saus Bolognese saja kaka"

F: "yo ga kakak, ini totalnya, silahkan ditunggu kakak e"

From the above conversation, it appears the cashier adapted the dialect according to the dialect used by the customers. In the initial interaction, the dialect used by the cashier did not show the language adaptation. But at the end of the conversation the dialect adaptation and the use of code switching with the interlocutors seemed very clear both in terms of accent, code switching between Manggaraian language (yo ga = $\mathrm{OK}$ ) and the use of the suffix $-\mathrm{E}$ which is the characteristic of Manggaraian community.

The use of adaptation that appears as in the conversation above is a potential marketing strategy to increase the selling power of the product. When someone who does not have the physical characteristics of a Manggaraian people speaks by using Manggaraian language, the customers will feel very comfortable to speak. In relation to this, Luna and Perachio, 2005 as cited in Brown and Altarrib (2007: 70) assert that "the code switching is shown to have advantages in the marketplace where it has been shown that persuasive advertising for products and services increases when... include code-switching to the first language".

\subsection{The existence of Language Variations Outside the Dialect of the Employees}

Indonesian language has a variety of variations due to its wide usage in society. This gave rise to various dialects used in communication, both among certain dialect speakers and with speakers from outside. But at present, the use of other dialects that are not dialects of speakers involved in interaction is a phenomenon of language use in our society. For example the Manggaraian people who speak using Javanese dialect when talking to fellow who is Manggaraian too. 
In the context of communication between the employees who have a multicultural background, phenomena such as those mentioned above also appear in casual situations where employees who are NTT residents occasionally use Timorese dialects in their communication.

D: "Lu su makan kow?, lu su makan? “

C: "belum.. beta su lapar nih".

D: "na lu pung perut tuh talalu lebe"

In the above conversation, in addition to the intonation in uttering the sentences that follow the Timorese dialect, several words used are also Indonesian words that have been influenced by the dialect such as pronoun like $l u$, and beta, and other words such as su, pung, and talalu.

Although the purpose of using the Timorese dialect was only to joke and strengthen the relationship among them, the factor of Timorese dialect prestige caused the emergence of this communication pattern. The Timorese dialect is one of the dialects used in the island of Timor, which is the administrative center of the province of NTT. Thus, this dialect has high prestige in the eyes of young people in other regions of NTT. So, they will feel cool if they can speak in this dialect even though some have never set foot on the island of Timor.

\subsection{The emergence of the Manggarai-Javanese dialect}

The efforts of speakers of other languages to adapt their language to the language of the local population bring out a variety of new and unique local languages when the regional characteristics of speakers of foreign languages retain the characteristics of their native language. This kind of effort is motivated by the desire to be accepted in a new society. Gudykust and Kim as quoted in Arianto (2012: 2) assert that "in every situation the person seems to know what group he (or she) belongs to and to what group he (or she) does not belong to. He(or she) knows more or less clearly where he (or she) stands, and this position largely determines his (or her) behavior".

When a person interacts with a new community, the culture is foreign to him. Therefore, understanding the new culture is a demand for him to feel accepted. For example, the Javanese in Manggarai. To be accepted in Manggaraian community, people who come from outside must understand Manggaraian culture, both in terms of language, communication patterns, customs and so on. To achieve this, of course, continuous communication is needed so that the so-called cultural manipulation is born. Cultural manipulation aims to create communication that is mutually understanding in the context 
of each culture. In the conversation excerpt below, someone from Java is having a conversation with an employee from Manggarai.

D: "Mas, siapa sudah namanya itu cewek yang kemarin datang"

E: "yang mana ya. toe baen enu"

In the excerpt above, employees from Java speaks Manggaraian language but the Javanese dialect cannot be removed (medok). In dealing with a new social situation or environment, one can choose to do a number of things depending on the motives of manipulating his ethnic identity by adapting to his new environment, maintaining his identity or adjusting to the situation wherever he is. Related to this DeVos (1975: 7) suggests "that social identity or ethnic identity is the most important factor including the use of some aspects of a group's cultural background to separate them from others".

\section{Conclusion}

There are four communication patterns that arise based on the results of the study and the discussion of the existence of language maintenance which is influenced by the situation factors, where in the formal situation the interaction pattern is dominated by language maintenance of each employee who has a multicultural background. The second pattern is that there is language adaptation carried out by the employees from outside Manggarai with the Manggaraian language. This occurs when they are in an informal situation and the purpose of the adaptation is to create intimacy between them. The third pattern is the emergence of another dialect outside the language of the employees' languages. In this case, the employees used Timorese dialect even though none of them come from Timor Island and this was influenced by the dialect prestige factor. The last pattern is the existence of the Manggarai-Javanese language where employees from Java speak using Manggaraian language but still retain their typical Javanese characteristics such as Javanese intonation. This kind of cultural manipulation emerges due to the desire to be accepted in the new society. This research reveals evidence on how dialect strategies used differently across communication context in society.

\section{References}

[1] Arianto. 2012. Manipulasi Identitas Etnik Jawa dalam Komunikasi Antar Budaya di Kota Makassar. Jurnal IImu Komunikasi, Volume 10, Nomor 3, Agustus 2012, halaman 295-307 
[2] Brown, D.M.B and Altarriba J. 2007. Code -switching and Code Mixing in Bilinguals: Cognitive, Developmental, and Empirical Approaches. New York: Nova Science Publisher inc.

[3] Chaer, Abdul. 2012. Linguistik Umum. Jakarta: Rineka Cipta.

[4] Chaer, A. and Agustin, L. 2004. Sosiolinguistik Perkenalan Awal. Jakarta: Rineka Cipta

[5] Chaer A. 1995. Pengantar Semantik Bahasa Indonesia. Jakarta: Rineka Cipta

[6] Fasold, R. 1994. The Sociolinguistics of Society. Oxford: Basil Blackwell

[7] Keraf, G. 1997. Komposisi: Sebuah Pengantar Kemahiran Bahasa. Ende-Florres: Nusa Indah

[8] Pateda, Mansoer. 1987. Sosiolinguistik. Bandung: Angkasa.

[9] Pauwels Anne. 2004. "Language maintenance". The Handbook of Appied Linguistic. Alan Davies and Catherine Elder. Maiden: Blackwell Publishing.

[10] Santoso, B. 2012. Bahasa dan Identitas Budaya. Sabda Volume 1 Nomor 1 September 2006 Universitas Dian Nuswantoro. 